\title{
Dynamics of diatom viruses on the western coast of Japan
}

\author{
Yuji Tomaru ${ }^{1, *}$, Naoki Fujiii ${ }^{2}$, Shigeyuki Oda ${ }^{3}$, Kensuke Toyoda ${ }^{1,4}$, Keizo Nagasaki $^{1}$ \\ ${ }^{1}$ National Research Institute of Fisheries and Environment of Inland Sea, Fisheries Research Agency, 2-17-5 Maruishi, \\ Hatsukaichi, Hiroshima 739-0452, Japan \\ ${ }^{2}$ Fukuoka Fisheries and Marine Technology Research Center Ariakekai Laboratory, 728-5 Yoshitomi, Yanagawa, \\ Fukuoka 832-0055, Japan \\ ${ }^{3}$ Fukuoka Fisheries and Marine Technology Research Center Buzenkai Laboratory, 76-30 Unoshima, Buzen, \\ Fukuoka 828-0022, Japan \\ ${ }^{4}$ Department of Botany, Keio University, 4-1-1 Hiyoshi, Kohoku-ku, Yokohama, Kanagawa 223-8521, Japan
}

\begin{abstract}
Diatoms are prominent primary producers that play an important role in global carbon cycles. Diatom dynamics are, therefore, important for biogeochemistry, fisheries and earth science. Viral infection is now assumed to be one of the most significant factors affecting diatom dynamics. However, few studies, based on practical field data, have focused on the relationship between diatoms and viruses in natural waters. To elucidate on this relationship, we assessed the temporal change in the abundance of diatoms and their viruses on the western coast of Japan from 2004 to 2009. Three species of diatoms were used as hosts to enumerate viruses in water and sediment samples: Chaetoceros debilis, C. tenuissimus and C. salsugineum. Diatom viruses in the water column rapidly increased during $C$. debilis and $C$. tenuissimus blooms, maintaining a high abundance throughout the blooming period. These data suggest the potential importance of viruses in controlling the population dynamics of diatoms in natural environments. The number of viruses in sediments fluctuated considerably, even during non-blooming periods, which suggests that virus-infected diatom cells were supplied to the sediments from water-column populations throughout the year. This process might be an important strategy to reduce the impact of viruses on diatom populations. Because diatom populations are thought to have an intimate relationship with their viruses in natural waters, further studies of diatom dynamics should include the effects of viral infections.
\end{abstract}

KEY WORDS: Diatom $\cdot$ Population dynamics $\cdot$ Virus $\cdot$ Chaetoceros $\cdot$ Sediment $\cdot$ Bloom $\cdot$ Survival strategy Resale or republication not permitted without written consent of the publisher

\section{INTRODUCTION}

The existence of diatom-infecting viruses was predicted based on transmission electron microscopic studies carried out 20 yr ago (Proctor \& Fuhrman 1991). It is only recently, however, that these viruses have been isolated. A diatom-infecting virus (RsetRNAV), lytic to Rhizosolenia setigera, was first isolated by Nagasaki et al. (2004a). Since then, 6 other diatom viruses infectious to the genus Chaetoceros have been isolated. These viruses are all lytic to their respective host cells, and their infection specificities are strainspecific rather than species-specific. Their virion diameters range from 22 to $38 \mathrm{~nm}$. Based on their genome characteristics, these viruses may be placed into at least 2 groups. One is a single-stranded RNA (ssRNA) virus group, which includes RsetRNAV, CtenRNAV (Shirai et al. 2008) and CsfrRNAV (Tomaru et al. 2009). Viruses in this group harbor an ssRNA genome, ca. $9 \mathrm{~kb}$ long, having 2 open reading frames, one of which encodes putative replication-related proteins, and the other, structural proteins (Tomaru et al. 2009). The second group comprises single-stranded DNA (ssDNA) viruses, including CsalDNAV and CdebDNAV. The genome of CsalDNAV consists of a single molecule of covalently closed circular ssDNA (6000 nt) and a segment of complementary strand linear ssDNA (997 nt; Nagasaki et al. 2005). Although the complete genome 
sequence and structure of CdebDNAV have not been fully described, the amino acid sequence deduced from the partial sequences is very similar to that of the putative replication-related protein of CsalDNAV (Tomaru et al. 2008b). Two other diatom viruses, CspNIV and CwNIV, which both infect Chaetoceros sp., have been isolated and their lytic cycles described; however, their genome types remain unknown (Bettarel et al. 2005, Eissler et al. 2009).

Diatom viruses have been isolated in both coastal waters and sediments, and their presence is assumed to be an influential ecological factor in the population dynamics of diatoms. Bettarel et al. (2005) reported on the occurrence of viruses that infect Chaetoceros sp. in the Chesapeake Bay, USA. They detected a maximum viral abundance one month after the winter-spring Chaetoceros bloom. They suggested that viral infection, due to an increase in the virus population in the water column, was the cause of the crash of the host Chaetoceros blooms. However, little field data has been gathered on the dynamics of diatom viruses, an area that would provide insight into the diatom hostvirus relationship in nature. In this study, we attempted to gather such data by assessing temporal changes of the populations of Chaetoceros debilis, C. tenuissimus and C. salsugineum in relation to virus abundance on the western coast of Japan, specifically in Ariake Sound and Hiroshima Bay.

\section{MATERIALS AND METHODS}

Field sampling. In Ariake Sound, field sampling was conducted from April 2004 through February 2008 at the mouth of the Shiotsuka River (ca. $13 \mathrm{~m}$ deep), and at the Itsukaichi Fishing Port in Hiroshima Bay (ca. $5 \mathrm{~m}$ deep), from April 2006 through March 2009 (Fig. 1). Ariake Sound is a semi-enclosed, shallow and productive estuarine system in western Japan with an area of $1700 \mathrm{~km}^{2}$ (e.g. Yokoyama et al. 2005). Diatom blooms are observed during winter and spring in this region (e.g. Nagasaki et al. 2004a). The Itsukaichi Fishing Port is a semi-enclosed basin in northern Hiroshima Bay, also in western Japan. In this area, raphidophyte and dinoflagellate blooms often occur from early summer to autumn (Imai \& Itakura 1999, Tomaru et al. 2004), and diatom blooms from winter to spring (Tomaru et al. 2009). Sampling was conducted once or twice per month throughout the 4 yr study. In Ariake Sound, the water temperature of the surface layer $(0 \mathrm{~m})$ and the bottom-minus-1 $\mathrm{m}(\mathrm{B}-1 \mathrm{~m})$ layer were measured using a Chlorotec Model ACL1183-PDK (Alec Electronics). In Hiroshima Bay, the temperature of the $0 \mathrm{~m}$ layer and the bottom-minus- $0.2 \mathrm{~m}(\mathrm{~B}-0.2 \mathrm{~m})$ layer were measured using an ST meter Model

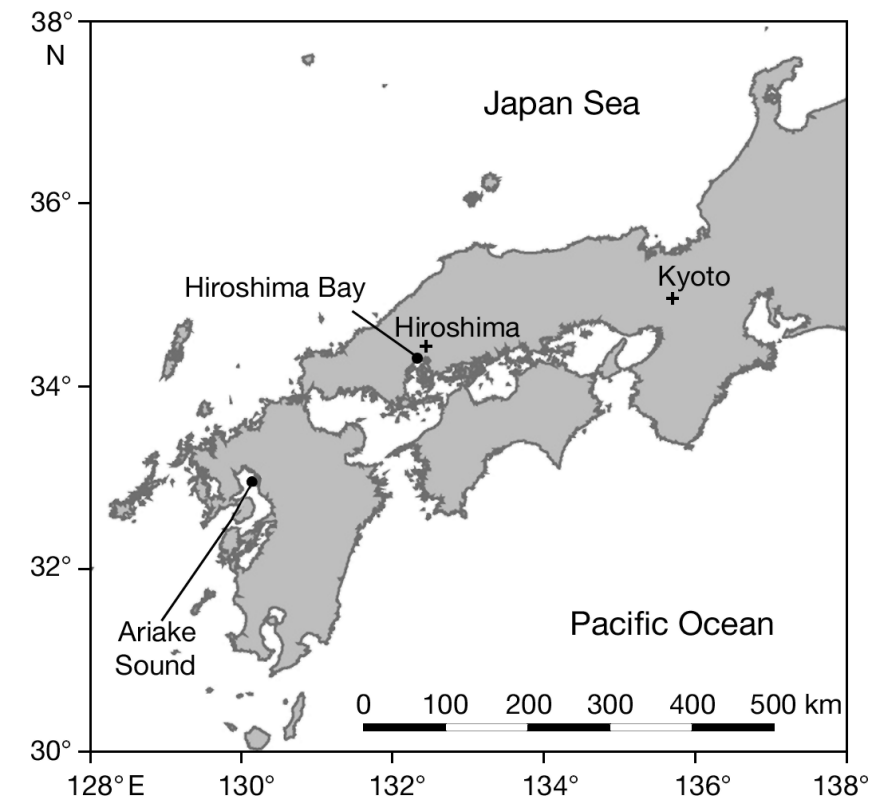

Fig. 1. Chaetoceros spp. Location of sampling areas: Ariake Sound (at mouth of Shiotsuka River) and Hiroshima Bay (at Itsukaichi Fishing Port) in western Japan

600XLM (YSI/Nanotech). Seawater samples were collected from each layer (simultaneously with temperature measurement) using a 11 Kitahara's water bottle (Tsurumi Seiki). In both Ariake Sound and Hiroshima Bay, sediment samples were collected using an Ekman-Birge bottom sampler, with sampling in Ariake Sound being performed to $3 \mathrm{~cm}$ depth and in Hiroshima Bay, to $1 \mathrm{~cm}$. Phytoplankton abundance was assessed by direct count using optical microscopy (Nikon Optiphoto for Ariake waters and an inverted Nikon TE300 for Hiroshima Bay waters). Water samples of 60 to $150 \mu \mathrm{l}$ with no fixation were dropped on a slide glass and a cover glass placed over the sample, with a $\sim 1$ mm plastic spacer between. We identified and counted phytoplankton to genus level. (When in bloom, Chaetoceros was occasionally identified to C. debilis.) Seawater and sediment samples collected for viral enumeration were sent to the laboratory of the National Research Institute of Fisheries and Environment of the Inland Sea, Japan (FRA-FEIS) without fixation at $4^{\circ} \mathrm{C}$. The titer of the viruses lytic to host diatoms (virus titration) was performed within $24 \mathrm{~h}$ of collection (see 'Abundance of lytic viruses', below). Parameters measured in each of the 2 water layers sampled were averaged. For testing the relationship between $C$. tenuissimus cells and their virus numbers, as well as temporal changes of host and virus numbers, statistical analyses using the Mann-Whitney $U$-test and Spearman's rank correlation test were performed using the STAT VIEW program (ver. 2.0.2, Abacus Concepts). 
Algal cultures and growth conditions. The algal strains Chaetoceros debilis Ch48 and C. debilis CC-8 (Tomaru et al. 2008b), C. tenuissimus 2-10 (Shirai et al. 2008) and C. salsugineum Ch42 (Nagasaki et al. 2005) were used in the virus titrations. (All strains are maintained at FRA-FEIS.) Each strain of C. debilis has a different virus sensitivity spectrum (Tomaru et al. 2008b). C. debilis Ch48 and CC-8 were used for the surveys in Ariake Sound and C. tenuissimus 2-10 and C. salsugineum Ch42 for those in Hiroshima Bay. Algal cultures were grown in modified SWM3 medium enriched with $2 \mathrm{nM} \mathrm{Na}_{2} \mathrm{SeO}_{3}$ (Chen et al. 1969, Itoh \& Imai 1987) under a $12 \mathrm{~h}$ light:12 h dark cycle of ca. 110 to $150 \mu \mathrm{mol}$ of photons $\mathrm{m}^{-2} \mathrm{~s}^{-1}$ using cool white fluorescent illumination at $15^{\circ} \mathrm{C}$.

Abundance of lytic viruses. The abundance of lytic viruses in seawater samples was estimated using the most probable number (MPN) technique (i.e. extinction dilution method; Suttle 1993). Water samples were passed through a $0.2 \mu \mathrm{m}$ membrane filter (Dismic-25cs, Advantec). Of each sediment sample, $3 \mathrm{~g}$ were shaken with $3 \mathrm{ml}$ of the modified SWM3 medium at $400 \mathrm{rpm}$ for $30 \mathrm{~min}$, then centrifuged at $716 \times g$ for $10 \mathrm{~min}$ at $4^{\circ} \mathrm{C}$. The supernatant was filtered through a $0.2 \mu \mathrm{m}$ Dismic-25cs filter (Advantec) to remove bacteria. These filtrates were diluted with modified SWM3 medium in a series of 10 -fold dilution steps. Aliquots $(100 \mu \mathrm{l})$ of each dilution were added to 8 wells in cellculture plates with 96 flat-bottom wells and mixed with $150 \mu \mathrm{l}$ of an exponentially growing culture of host algae. The cell-culture plates were incubated at $15^{\circ} \mathrm{C}$ under a $12 \mathrm{~h}$ light:12 h dark cycle of 130 to $150 \mu \mathrm{mol}$ photons $\mathrm{m}^{-2} \mathrm{~s}^{-1}$ with cool white fluorescent illumination, and were monitored over $14 \mathrm{~d}$ for the occurrence of culture lysis using optical microscopy (TE-300, Nikon). The culture lysis due to viral infection was usually observed as almost complete crashes of the host cells in a well. Algal lysate in the most-diluted wells was filtered through a $0.2 \mu \mathrm{m}$ filter and the infectivity of the lytic agents examined. We regarded these filterable lytic agents as infectious viruses and, using a BASIC program, calculated their abundance from the number of wells in which algal lysis occurred (Nishihara et al. 1986).

Real-time PCR assay. The number of Chaetoceros tenuissimus and C. salsugineum cells in the water column of Hiroshima Bay from April 2008 to March 2009 was estimated by means of real-time PCR assay using a TaqMan probe-based method. Sample-water suspensions (from 30 to $50 \mathrm{ml}$ ) were filtered onto $2.0 \mu \mathrm{m}$ Nucleopore filters and stored at $-80^{\circ} \mathrm{C}$ until analysis. DNA was extracted from the filter-collected cells using the Tris-EDTA (TE) buffer ( $\mathrm{pH}$ 8) boiling method. Briefly, the filters were placed in a $0.5 \mathrm{ml}$ tube and incubated in $100 \mu \mathrm{l}$ of $\mathrm{TE}$ at $100^{\circ} \mathrm{C}$ for $10 \mathrm{~min}$, then stored at $4^{\circ} \mathrm{C}$. After centrifugation at $17000 \times g$ for $5 \mathrm{~min}, 100 \mu \mathrm{l}$ of the supernatant was taken for further analysis using 2 primer sets and a TaqMan probe designed to target the D1 region of the 28S ribosomal RNA gene of the target organism (Table 1). The primer pairs and probes for C. tenuissimus and C. salsugineum were designed by Toyoda et al. (2010) and Tomaru et al. (present study), respectively (Table 1). The species specificities of both the primer pair and the probe for the quantification of $C$. salsugineum cells were examined and cell numbers were quantified according to the TaqMan method of Toyoda et al. (2010). The following reagents were combined to make up a $20 \mu$ reaction mixture: (1) forward and reverse primers (each at a final concentration of 0.4 $\mu \mathrm{M})_{i}(2)$ the fluorogenic probe at a final concentration of $0.2 \mu \mathrm{M}_{\text {; }}$ (3) $1 \mu \mathrm{l}$ of template DNA; (4) $10 \mu \mathrm{l}$ of $2 \times$ TaqMan ${ }^{\circledR}$ Gene Expression Master Mix (containing PCR buffer, dNTPs, $\mathrm{MgCl}_{2}$, and AmpliTaq Gold DNA polymerase; Applied Biosystems Japan); and (5) PCRgrade water to a final volume of $20 \mu$ l. The thermal cycling conditions consisted of $2 \mathrm{~min}$ at $50^{\circ} \mathrm{C}$ and 10 min at $95^{\circ} \mathrm{C}$ followed by 39 cycles of $15 \mathrm{~s}$ at $95^{\circ} \mathrm{C}$ and 1 min at $60^{\circ} \mathrm{C}$ using a StepOne ${ }^{\mathrm{TM}}$ Real-Time PCR System (Applied Biosystems Japan). Fluorescence data were collected at the end of each cycle, and the cycle threshold line was automatically determined by StepOne ${ }^{\mathrm{TM}}$ Real-Time PCR System version 1.0 (Applied Biosystems Japan).

Table 1. Primers and TaqMan probes, targets and sequences. FAM: carboxyfluorescein; NFQ: non-fluorescent quencher; MGB: minor groove binder

\begin{tabular}{|c|c|c|}
\hline Primer or probe & Target & Sequence $\left(5^{\prime}-3^{\prime}\right)$ \\
\hline Primer 2-10_EF ${ }^{\mathrm{a}}$ & Chaetoceros tenuissimus & TTG TGG AGA GGT ACG CTT GTC TT \\
\hline Primer 2-10_ER ${ }^{\mathrm{a}}$ & Chaetoceros tenuissimus & CCC TCA TAG GCA CCC TGT TC \\
\hline 2-10_SetE_Probe ${ }^{a}$ & TaqMan probe for 2-10 primer set & FAM - CCT TAG CTT AAA TCT CT - NFQ - MGB \\
\hline Primer Ch42_AF ${ }^{\mathrm{b}}$ & Chaetoceros salsugineum & TAG AAG ATG TGT CGG ACT AGA CT \\
\hline Primer Ch42_AR ${ }^{\mathrm{b}}$ & Chaetoceros salsugineum & ACA CGT TAA AGC CAA GGC CAG AA \\
\hline Ch42_SetA_Probe ${ }^{\mathrm{b}}$ & TaqMan probe for Ch42 primer set & FAM - AGA TCT ATT TCA GAT TGA AGA CT - NFQ - MGB \\
\hline a'Toyoda et al. (2010 & ${ }^{\mathrm{b}}$ Present study & \\
\hline
\end{tabular}




\section{RESULTS AND DISCUSSION}

\section{Viruses infecting Chaetoceros debilis in Ariake Sound}

Blooms of Chaetoceros debilis are usually detected in Japanese coastal waters during winter (Takano 1990). Increases in the number of $C$. debilis viruses (Cdeb-viruses) in the water column were observed almost every year between November and April, when water temperatures are relatively low (Fig. 2A,C). The increased number of Cdeb-viruses observed in the water column during winter in this survey, therefore, may correspond to an increase in host blooms. In this study, no data were available on the population dynamics of C. debilis. However, on 19 January 2005

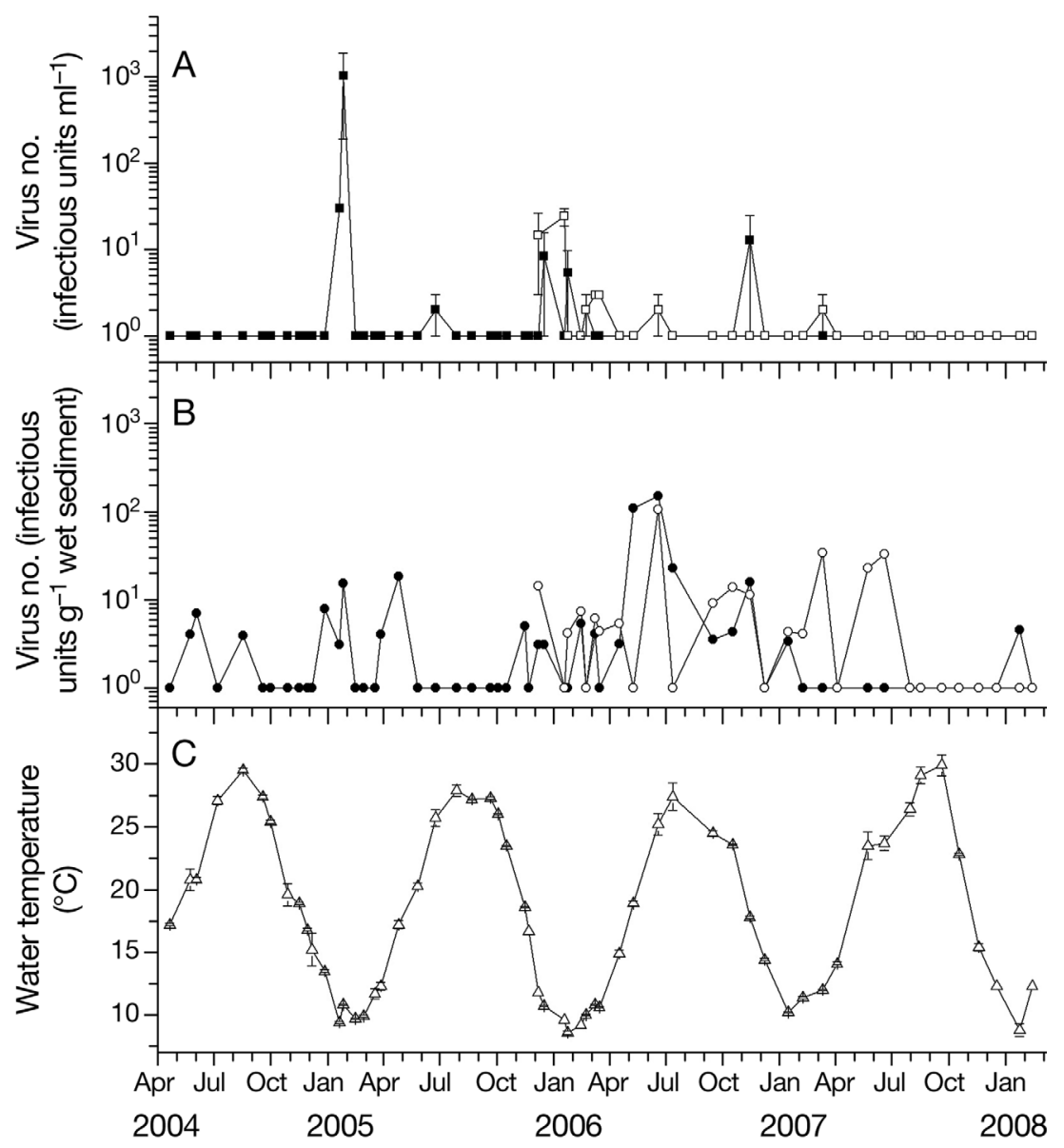

Fig. 2. Temporal changes in abundance of viruses infecting Chaetoceros debilis in (A) water column, (B) sediments, and (C) water temperatures recorded in Ariake Sound. Water temperatures and virus numbers in water column are averages of surface and bottom-minus-1 m (B-1m) layers (see text). Error bars indicate difference in surface and B-1m values and are visible when they exceed the size of the symbol. Host strains measured were Ch48 (ם) and CC-8 $(\square)$ in the water column and $\mathrm{Ch} 48(\bullet)$ and CC-8 $(O)$ in sediments. Host strain Ch48 was used to enumerate viruses from April 2004 to February 2008; CC-8 was used from December 2005 to February 2008 we observed a bloom (200 cells $\mathrm{ml}^{-1}$ at the surface) of C. debilis. This corresponded to a time when Cdebviruses lytic to strain Ch48 (Ch48-viruses) were detected in the water column at 30 infectious units $\mathrm{ml}^{-1}$ (Fig. 2A). One week later, on 27 January 2005, the bloom was no longer detected, and the concentration of Ch48-viruses had increased to $1.0 \times 10^{3}$ infectious units $\mathrm{ml}^{-1}$. The significant peak in the viruses detected in the water column in late January 2005 (Fig. 2A) may be related to disintegration of the $C$. debilis bloom.

Since 2 strains of Chaetoceros debilis (Ch48, CC-8) wing diverse virus sensitivity spectra (Tomaru et al. 8b) were used as hosts to enumerate Cdeb-viruses, assumed we were actually measuring 2 types of viruses having different intra-species host specificities (viz. Ch48-viruses and CC-8-viruses). Interestingly, the dynamics of the 2 types of Cdebviruses differed in sediments (Fig. 2B). Although from December 2005 through December 2006 the fluctuation in their patterns were very similar, from January 2007 through July 2007 (except for April 2007) CC-8-virus abundance fluctuated at higher levels than those of Ch48viruses (from 4.1 to 34 infectious units $\mathrm{g}^{-1}$ wet sediment for CC-8-viruses vs. $<3.4$ infectious units $\mathrm{g}^{-1}$ wet sediment for Ch48-viruses; Fig. 2B). This suggests the existence of various Cdeb-virus clones in natural environments with different host-strain specificities. Based on crossreactivity tests carried out among 29 virus clones and 23 strains of $C$. debilis, Tomaru et al. (2008b) suggested that the natural C. debilis population comprises a diversity of host strains with different spectra of virus sensitivity. They also hypothesized that this host-strain diversity is likely to sustain the population from attack by viruses that vary in the specificity of their infections (Tomaru et al. 2008b). The results obtained during the present study appear to support this hypothesis, at least in part.

The number of viruses present in sediment fluctuated throughout the survey, including periods when numbers in the water column were below the detection limit (Fig. 2A,B). Since there is an energy cost for the diatoms to stay suspended in the water column (Waite et al. 1992), cells damaged physiologically by viral infection might have a tendency to sink to the bottom layer of the column (Proctor \& Fuhrman 1991, Raven \& Waite 2004). Our 
results suggest that $C$. debilis populations are exposed to viral infection even during non-bloom periods and, consequently, virus-infected cells sink to the bottom layer, thereby minimizing or preventing further viral diffusion in the water column. For further understanding of the ecology of the host-virus system in this region, the sinking rates of virus-infected C. debilis cells and the latent periods of various environmental factors (e.g. water temperature, salinity, light intensity and nutrient conditions) should be the focus of future studies.

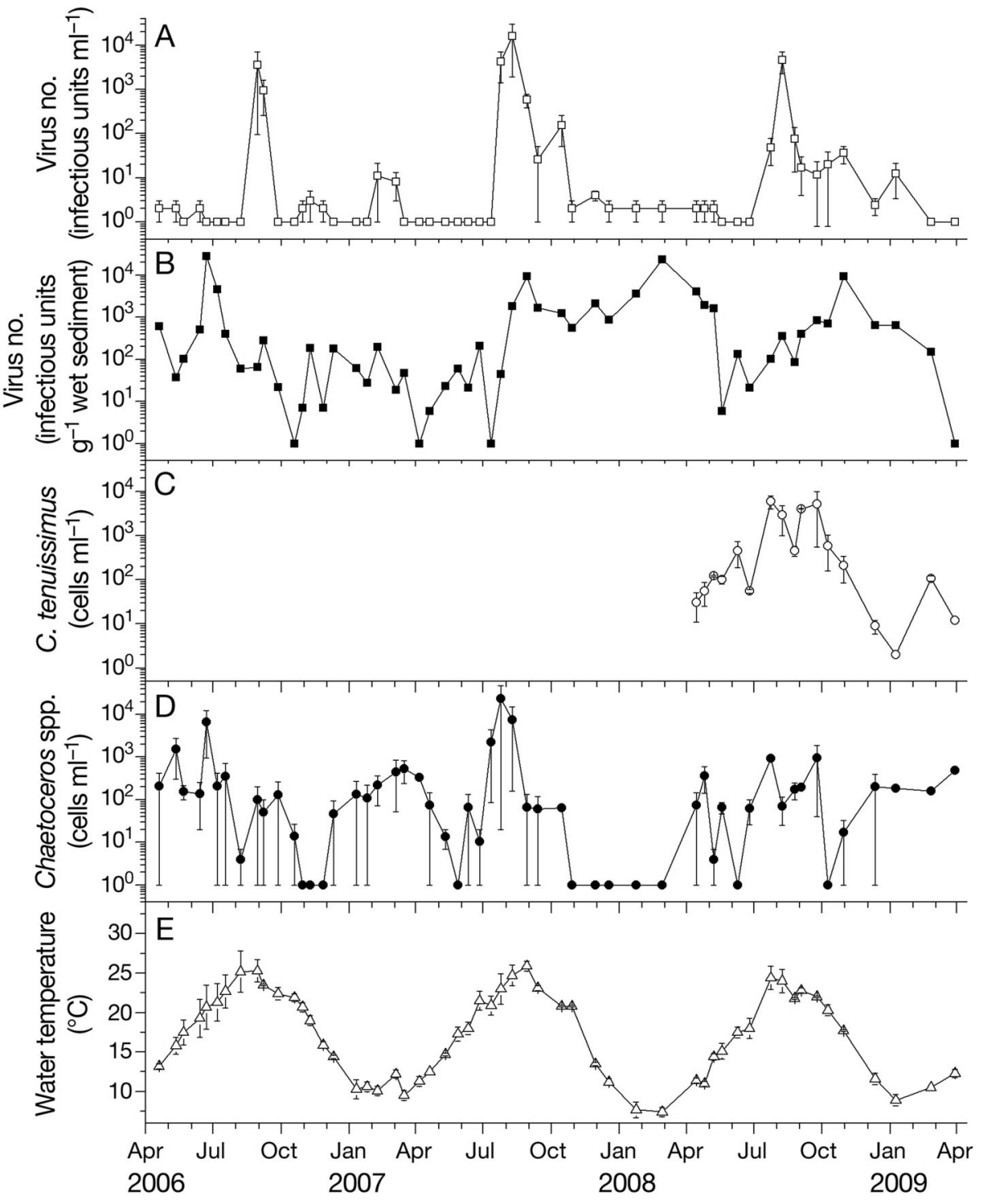

Fig. 3. Temporal changes in abundance of viruses infecting Chaetoceros tenuissimus (A) in the water column and (B) in sediments; changes in the abundance of (C) $C$. tenuissimus cells and (D) Chaetoceros spp. cells in the water column; and (E) water temperature recorded in Itsukaichi Fishing Port, Hiroshima Bay. Water temperatures and values of each parameter in the water column are averages of surface and bottom-minus-0.2 m (B-0.2m) values (see text). Error bars indicate differences in surface and B- $0.2 \mathrm{~m}$ values and are visible when they exceed the size of the symbol. Numbers of Chaetoceros spp. and C. tenuissimus cells were measured by optical microscopy and real-time PCR, respectively
A rapid increase in the Chaetoceros tenuissimus virus (Cten-virus) in the water column was observed every year, from July to August, throughout the survey (Fig. 3A). While the cell density of Chaetoceros spp. was monitored in parallel by optical microscopy, we realized that the dominant species of the Chaetoceros spp. bloom $\left(2.3 \times 10^{4}\right.$ cells $\left.\mathrm{ml}^{-1}\right)$ on 25 July 2007 was in fact C. tenuissimus (Fig. 3D). We sampled the dominant Chaetoceros cells and attempted species identification by real-time PCR using both the species-specific primers and the TaqMan-probe, targeting the nuclear ribosomal DNA internal-transcribed-spacer 1 (ITS1) region of C. tenuissimus (Y. Tomaru unpubl. data). At least $75 \%$ of the sampled Chaetoceros chain-forming colonies were identified as C. tenuissimus (Y. Tomaru unpubl. data). During the observed Chaetoceros bloom period, which, in 2007, continued until 9 August, the number of Ctenviruses increased rapidly both in the water column (reaching $1.6 \times$ $10^{4}$ infectious units $\mathrm{ml}^{-1}$ ) and sediments (reaching 9.2 $\times 10^{3}$ infectious units $\mathrm{g}^{-1}$ wet sediment; Fig. 3A,B,D). The increased Ctenvirus count during this period is likely related with that host bloom. In the previous year, the rapid increases of Cten-viruses to $3.6 \times 10^{3}$ infectious units $\mathrm{ml}^{-1}$ on 30 August 2006 (Fig. 3A) might be related with its host blooms as well.

The abundance of Cten-virus in sediments fluctuated significantly throughout the study period, but remained relatively high between August 2007 and May 2008 (from $5.7 \times 10^{2}$ to $2.4 \times 10^{4}$ infectious units $\mathrm{g}^{-1}$ wet sediment; Fig. 3B). Considering that Cten-viruses were continuously detected in the water column during that period, there might have been stable hostcell growth with virus infection and propagation in the water column, resulting in an input of infected cells into the sediments. 
Since, from May to June 2006, the number of Ctenviruses in sediments increased 3 orders of magnitude (from $3.7 \times 10^{1}$ to $2.8 \times 10^{4}$ infectious units $\mathrm{g}^{-1}$ wet sediment; Fig. 3B), a similar process might have been occurring at this time.

The temporal change in the number of Chaetoceros tenuissimus in the water column from April 2008 to March 2009 was measured by real-time PCR (Fig. 3C). The bloom of this species was detected from 24 July through 9 October 2008, when cell numbers fluctuated between $4.5 \times 10^{2}$ and $5.9 \times 10^{3}$ cells ml ${ }^{-1}$. At the initial stage of the bloom, the number of Cten-viruses in the water column showed a significant peak $\left(4.6 \times 10^{3}\right.$ infectious units $\mathrm{ml}^{-1}$ ), after which the number of $C$. tenuissimus cells temporarily decreased (Fig. 3A,C). Following the decrease in abundance, the host population recovered and stabilized at $>10^{3}$ cells $\mathrm{ml}^{-1}$, despite the presence of the virus at $>10$ infectious units $\mathrm{ml}^{-1}$ (Fig. 3A,C). The coexistence of $C$. tenuissimus and their infectious viruses during this bloom period (Fig. 3) indicates that the host populations have strategies to escape complete disintegration by viral infection. Although there is no direct evidence showing such a strategy among $C$. tenuissimus, there are grounds for speculation. A C. tenuissimus clonal culture, even when inoculated with its lytic virus (CtenRNAV) at a high multiplicity of infection, was observed to grow at a rate equal to that of an uninfected culture for 10 to $14 \mathrm{~d}$ (Shirai et al. 2008). This result indicates that $C$. tenuissimus cells have diverse sensitivities to viral infection even in a clonal culture (Shirai et al. 2008). In natural environments, therefore, the host population might also be expected to be composed of highly diverse cells with different viral sensitivities. So far, at least 2 viruses infecting $C$. tenuissimus have been recognized: CtenRNAV (Shirai et al. 2008) and the recently identified CtenDNAV, which harbors a closed, circular single-stranded DNA genome (Y. Tomaru unpubl. data). The viral sensitivity spectra of C. tenuissimus strains to these viruses are diverse (Y. Tomaru unpubl. data) and this variation might protect the population from rapid decrease due to viral infection. Similar hypotheses have been proposed in studies on Heterosigma akashiwo and $\mathrm{HaV}$ (Tomaru et al. 2008a), and Chaetoceros debilis and its viruses (Tomaru et al. 2008b).

In sediments, on the other hand, we observed Cten-viruses to gradually increase in abundance throughout the 2008 blooming period (Fig. 3B,C). This gradual increase in sediment virus numbers may indicate that part of the $C$. tenuissimus population was infected, then sank to the bottom, furnishing the sediment with viruses as mentioned above with respect to Cdeb-viruses. The depth of the sampling station in Hiroshima Bay (ca. $5 \mathrm{~m}$ ) might be too shal- low for the sedimentation of the virus-infected $C$. tenuissimus cells.

The number of Chaetoceros tenuissimus cells increased again from January to March 2009, at a time when virus numbers in both water column and sediments decreased (Fig. 3C). This might suggest that host population growth in this period was not greatly affected by virus infections. Relatively low host-cell numbers $\left(<10^{2}\right.$ cells $\left.\mathrm{ml}^{-1}\right)$ and/or low water temperatures $\left(<12.5^{\circ} \mathrm{C}\right)$ might not lead to viral propagation. It is, however, difficult to suggest on the basis of present data a reason for the failure of virus numbers to increase with host population growth.

The number of Cten-viruses in the water column is relatively higher when Chaetoceros tenuissimus cell numbers are $>200$ cells $\mathrm{ml}^{-1}$ (Mann-Whitney $U$-test, $\mathrm{p}<0.01$ ). Similar results have been reported for Synechococcus and cyanophage systems in natural waters, where host cell densities of $>10^{3}$ cells ml $\mathrm{m}^{-1}$ allowed for efficient viral propagation (Suttle \& Chan 1994). The present results could suggest that a minimum host-cell density threshold of ca. 200 cells ml-1 is required for the effective propagation of Cten-viruses in a water column.

\section{Viruses infecting Chaetoceros salsugineum in Hiroshima Bay}

Chaetoceros salsugineum viruses (Csal-viruses) were detected at high frequency in the water column and sediments from August 2006 to October 2007. Maximum detected abundance in water was $3.1 \times 10^{4}$ infectious units $\mathrm{ml}^{-1}$, and, in sediment, $3.3 \times 10^{4}$ infectious units $\mathrm{g}^{-1}$ wet sediment (Fig. 4A,B). During that period, we could not enumerate host abundance using a real-time PCR method, and, unfortunately, no $C$. salsugineum cells could be detected using light microscopy. No significant relationship was observed between the dynamics of Csal-viruses and Chaetoceros spp. populations within this timeframe (Fig. 4A,B,D; Spearman's rank correlation, $p>0.05$ ). Viral fluctuations during that period, however, suggest the existence of a sufficient host population density to efficiently propagate viruses in the bay.

Using real-time PCR, a low-density bloom of Chaetoceros salsugineum (from 10 to 30 cells $\mathrm{ml}^{-1}$ ) was detected from July through September 2008, gradually decreasing thereafter (Fig. 4C). No Csal-viruses were detected in the water column during this period (Fig. 4A). This may suggest that the host-cell densities in the water column were not great enough for efficient viral propagation there.

From November 2007 through April 2009, fluctuating levels of Csal-viruses were continuously detected in 


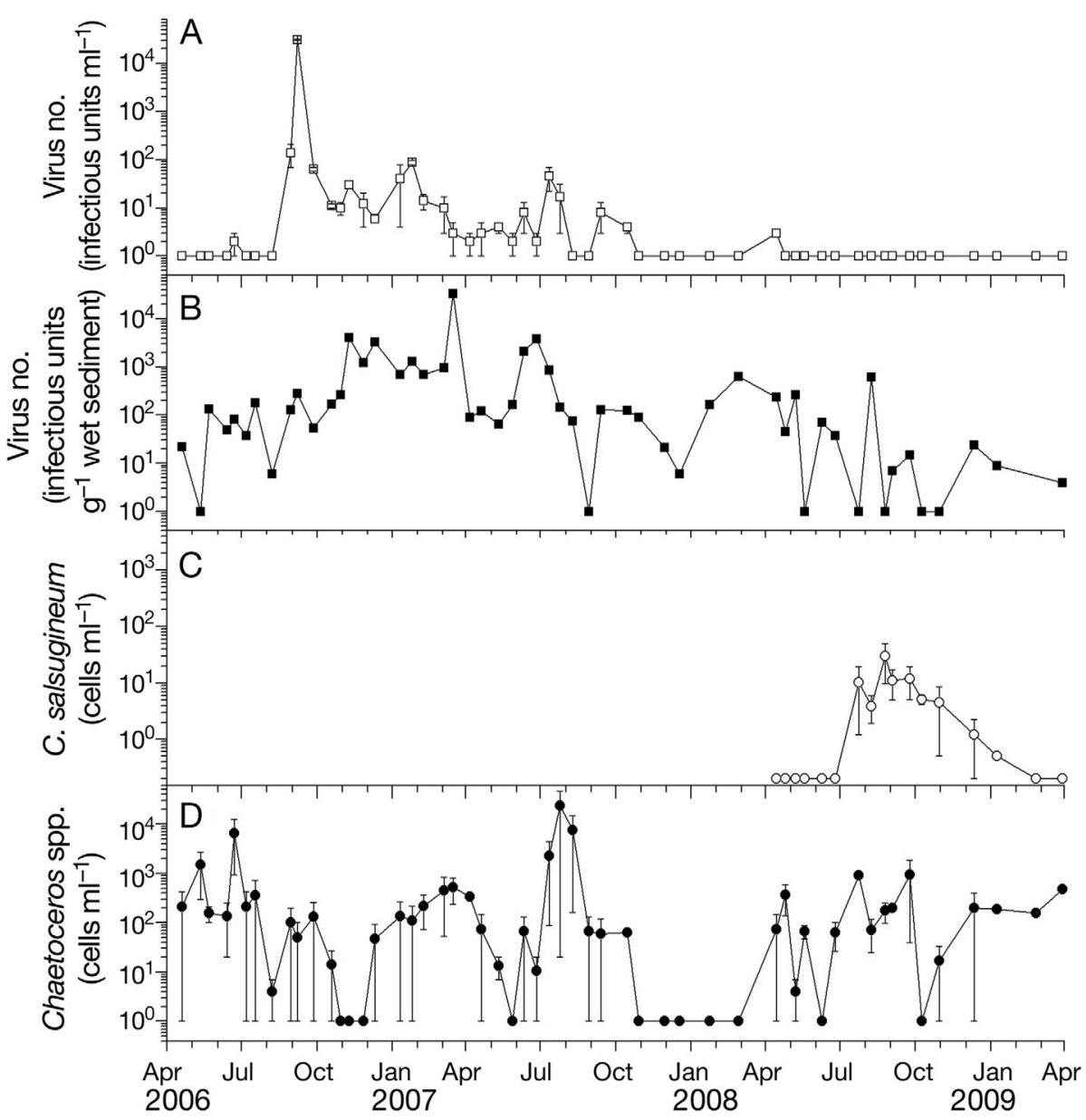

Fig. 4. Temporal changes in abundance of viruses infecting Chaetoceros salsugineum (A) in the water column and (B) in sediments; (C) changes in abundance of C. salsugineum cells and (D) Chaetoceros spp. cells in the water column recorded in Itsukaichi Fishing Port, Hiroshima Bay. Values of each parameter in the water column are averages of surface and bottom-minus- $0.2 \mathrm{~m}$ (B- $0.2 \mathrm{~m})$ values (see text). Error bars indicate differences in surface and B- $0.2 \mathrm{~m}$ values and are visible when they exceed the size of the symbol. Numbers of Chaetoceros spp. and C. salsugineum cells were measured by optical microscopy and real-time PCR, respectively

\section{Implications}

It appears that diatom populations are affected by their infectious viruses even when viral concentrations are relatively low. Based on the present results, several hypotheses may be proposed concerning the strategies that diatom host populations employ to escape viral-induced destruction. Viral infection may cause infected cells to be transferred from the water column to the bottom via sedimentation (Lawrence \& Suttle 2004) and therefore removed from healthy populations (Raven \& Waite 2004). Also, diversity in the viral sensitivity spectra of the host population may enable hostvirus coexistence (Tomaru et al. 2008b). Outside of these possibilities, populations might be sustained by physiologically regulated viral resistance of diatom cells, as seen in Chaetoceros tenuissimus (Shirai et al. 2008), or by resting spore formations of host cells, as observed in Chaetoceros socialis f. radians (Tomaru et al. 2009).

Virus-induced disintegration of algal blooms (i.e. rapid decrease in host-cell number) has been reported in several systems, e.g. Heterosigma akashiwo (Raphidophyceae) and HaV (Tomaru et al. 2008a), Heterocapsa circularisquama (Dinophyceae) and sediments even when they were scarcely detected in the water column (Fig. 4A,B). This discrepancy indicates that Csal-viruses were continually being removed and added to sediments throughout the study period. The decrease in Csal-viruses in sediments might be due to degradation of the virions, re-suspension in the water column or other factors (Wommack \& Colwell 2000, Nagasaki et al. 2004b). The input of viruses into the sediment is thought to occur during sedimentation of virus-infected cells (Lawrence \& Suttle 2004). Even when both host and virus numbers are relatively low in a water column (from $<1$ to $\sim 10$ cells $\mathrm{ml}^{-1}$, and $<1$ infectious unit $\mathrm{ml}^{-1}$, respectively), successful viral infections might occur in this host-virus system, and the infected cells sink to the bottom.
HcRNAV (Nagasaki et al. 2004b) and Emiliania huxleyi (Prymnesiophyceae) and EhV (Brussaard et al. 1996, Schroeder et al. 2003). In the present study, Cdeb- and Cten-viruses, at least, were expected to show an increase in abundance in the water column and/or in sediments when their respective hosts bloomed, and they did so. However, based only on present results, the quantitative ecological impacts of a viral infection on diatom bloom dynamics cannot be fully understood. To increase our understanding of their relationships in nature, higher-frequency sampling will be required during diatom blooms, as well as an evaluation of the sinking rate of virusinfected cells and the quantitative impact of viruses on diatom host populations. 
Acknowledgements. This study was supported by a Grantin-Aid for Young Scientists (A) (22688016) from the Japanese Ministry of Education, Science, Sports and Culture, and by the Ministry of Agriculture, Forestry, and Fisheries of Japan.

\section{LITERATURE CITED}

Bettarel Y, Kan J, Wang K, Williamson K and others (2005) Isolation and preliminary characterisation of a small nuclear inclusion virus infecting the diatom Chaetoceros cf. gracilis. Aquat Microb Ecol 40:103-114

Brussaard CPD, Kempers RS, Kop AJ, Riegman R, Heldal M (1996) Virus-like particles in a summer bloom of Emiliania huxleyi in the North Sea. Aquat Microb Ecol 10: 105-113

Chen LCM, Edelstein T, McLachlan J (1969) Bonnemaisonia hamifera Hariot in nature and in culture. J Phycol 5: 211-220

Eissler Y, Wang K, Chen F, Wommack E, Coats W (2009) Ultrastructural characterization of the lytic cycle of an intranuclear virus infecting the diatom Chaetoceros cf. wighamii (Bacillariophyceae) from Chesapeake Bay, USA. J Phycol 45:787-797

Imai I, Itakura S (1999) Importance of cysts in the population dynamics of the red tide flagellate Heterosigma akashiwo (Raphidophyceae). Mar Biol 133:755-762

Itoh K, Imai I (1987) Rafido so (Raphidophyceae). In: Japan Fisheries Resource Conservation Association (ed) A guide for studies of red tide organisms. Shuwa, Tokyo, p 122-130 (in Japanese)

Lawrence JE, Suttle CA (2004) Effect of viral infection on sinking rates of Heterosigma akashiwo and its implications for bloom termination. Aquat Microb Ecol 37:1-7

Nagasaki K, Tomaru Y, Katanozaka N, Shirai Y, Nishida K, Itakura S, Yamaguchi M (2004a) Isolation and characterization of a novel single-stranded RNA virus infecting the bloom-forming diatom Rhizosolenia setigera. Appl Environ Microbiol 70:704-711

Nagasaki K, Tomaru Y, Nakanishi K, Katanozaka N, Yamaguchi M (2004b) Dynamics of Heterocapsa circularisquama (Dinophyceae) and its viruses in Ago Bay, Japan. Aquat Microb Ecol 34:219-226

Nagasaki K, Tomaru Y, Takao Y, Nishida K, Shirai Y, Suzuki H, Nagumo T (2005) Previously unknown virus infects marine diatom. Appl Environ Microbiol 71:3528-3535

Nishihara T, Kurano N, Shinoda S (1986) Calculation of most probable number for enumeration of bacteria on a microcomputer. Eisei Kagaku 32:226-228 (in Japanese)

Proctor LM, Fuhrman JA (1991) Roles of viral infection in organic particle flux. Mar Ecol Prog Ser 69:133-142
Raven JA, Waite AM (2004) The evolution of silicification in diatoms: inescapable sinking and sinking as escape? New Phytol 162:45-61

Schroeder DC, Oke J, Hall M, Malin G, Wilson WH (2003) Virus succession observed during an Emiliania huxleyi bloom. Appl Environ Microbiol 69:2484-2490

Shirai Y, Tomaru Y, Takao Y, Suzuki H, Nagumo T, Nagasaki $\mathrm{K}$ (2008) Isolation and characterization of a singlestranded RNA virus infecting the marine planktonic diatom Chaetoceros tenuissimus Meunier. Appl Environ Microbiol 74:4022-4027

Suttle CA (1993) Enumeration and isolation of viruses. In: Kemp PF, Sherr BF, Sherr EB, Cole JJ (eds) Handbook of methods in aquatic microbial ecology. Lewis Publishers, Boca Raton, FL, p 121-134

> Suttle CA, Chan AM (1994) Dynamics and distribution of cyanophages and their effect on marine Synechococcus spp. Appl Environ Microbiol 60:3167-3174

Takano H (1990) Chaetoceros debile Cleve. In: Fukuyo Y, Takano H, Chihara H, Matsuoka K (eds) Red tide organisms in Japan: an illustrated taxonomic guide. Uchida Rokakuho, Tokyo, p 286-287

- Tomaru Y, Tarutani K, Yamaguchi M, Nagasaki K (2004) Quantitative and qualitative impacts of viral infection on a Heterosigma akashiwo (Raphidophyceae) bloom in Hiroshima Bay, Japan. Aquat Microb Ecol 34:227-238

Tomaru Y, Shirai Y, Nagasaki K (2008a) Ecology, physiology and genetics of a phycodnavirus infecting the noxious bloom-forming raphidophyte Heterosigma akashiwo. Fish Sci 74:701-711

Tomaru Y, Shirai Y, Suzuki H, Nagumo T, Nagasaki K (2008b) Isolation and characterization of a new single-stranded DNA virus infecting the cosmopolitan marine diatom Chaetoceros debilis. Aquat Microb Ecol 50:103-112

Tomaru Y, Takao Y, Suzuki H, Nagumo T, Nagasaki K (2009) Isolation and characterization of a single-stranded RNA virus infecting the bloom-forming diatom Chaetoceros socialis. Appl Environ Microbiol 75:2375-2381

> Toyoda K, Nagasaki K, Tomaru Y (2010) Application of realtime PCR assay for detection and quantification of bloomforming diatom Chaetoceros tenuissimus Meunier. Plankton Benthos Res 5:56-61

- Waite A, Thompson PA, Harrison PJ (1992) Does energy control the sinking rates of marine diatoms? Limnol Oceanogr $37: 468-477$

Wommack KE, Colwell RR (2000) Virioplankton: viruses in aquatic ecosystems. Microbiol Mol Biol Rev 64:69-114

Yokoyama H, Tamaki A, Koyama K, Ishihi Y, Shimoda K, Harada K (2005) Isotopic evidence for phytoplankton as a major food source for macrobenthos on an intertidal sandflat in Ariake Sound, Japan. Mar Ecol Prog Ser 304: $101-116$

Submitted: September 13, 2010; Accepted: January 26, 2011 Proofs received from author(s): April 28, 2011
Editorial responsibility: Gunnar Bratbak, Bergen, Norway 